\title{
Constituting the Identity of an Elementary School Teacher in the 21st Century World of Teaching and Learning
}

\author{
M. Wangeci Gatimu ${ }^{1} \&$ Mary Mangan Reynolds ${ }^{1}$ \\ ${ }^{1}$ Division of Teacher Education, Western Oregon University, USA \\ Correspondence: M. Wangeci Gatimu, 1194 S. $6^{\text {th }}$ street, Independence OR. 97351, USA. E-mail: \\ gatimum@wou.edu
}

Received: September 27, 2012

Accepted: September 3, $2013 \quad$ Online Published: November 12, 2013

doi:10.5539/jel.v2n4p154

URL: http://dx.doi.org/10.5539/jel.v2n4p154

\begin{abstract}
The study uses teacher identity as a lens to explore how teachers make sense of their work and constitute professional identities in the often complex world of teaching and learning. Three teachers who completed the same teacher preparation program and taught in the same school district were observed and interviewed for the study in 2009-2010. A multiple case methodology was used to explore the question: How do teachers who go through the same teacher preparation program and teach in the same school district constitute their professional identities?

Findings indicate that school and district mandates have a strong influence in shaping teacher identities because these mandates appeared to either limit or distract teacher reflective practices. It was found that teachers caught up in the logic of the mandated curricular and assessments were less likely to use constructivist frameworks to understand student perspectives or to connect with the lived experiences of their students. On the other hand, it was found if a teacher was engaged in critical inquiry about teaching and learning, that teacher was likely to use multiple assessment strategies to understand students, and was likely to engage student learning through open-ended, classroom conversations.

We concluded that since a teacher is the single most important factor affecting student achievement, school districts should be forums for continuous teacher learning. The goal for such learning should be to create adaptive experts or - teachers who continually expand the breadth and depth of their expertise. Additionally, such learning should be both practice -centered and inquiry oriented.
\end{abstract}

Keywords: teacher education, inquiry, teacher learning and development, standards and standardized testing

\section{Introduction}

Teacher factor in student achievement was explained as the single most important factor affecting student achievement (Marzano 2003); unfortunately major reform initiatives in education during the $20^{\text {th }}$ century focused on everything but the quality of teachers (Darling-Hammond et al.. 2005). Given the critical importance of the teacher factor in student achievement, we think developing teacher quality should be viewed as a continuous process that begins at the teacher preparation programs and continues as a formal and informal personal and professional development throughout a teaching career. The process of learning to teach also involves different kinds of individually developed knowledge constructed in and through interaction in and outside classroom contexts (Jurasaite-Harbinson, 2005). In this paper, we investigate how teacher identity - defined as the outcome of the interaction between personal experience and the social, cultural and institutional context in which a teacher performs the task of teaching ((Jurasaite-Harbinson, 2005)- is likely to impact P12 student learning.

Most recently, the discourse of teacher quality has moved to the center stage in the United States. Under the banner of Blue Ribbon Panel led by the National Council for Accreditation of Teacher Education (NCATE), a group of well placed educators declared " The education of teachers in the United States needs to be turned upside down (NCATE, November 2010 p. i)." To be fair, this statement was made in the context of a proposal to link academic preparation to teaching practice in line with medical doctors' training. But can teachers be effective just because their university preparation programs are closely linked to P12 pre-service teaching? We argue that while rethinking teaching practice is a step in the right direction, preparing effective teachers is a far more complex phenomenon that should be continuously interrogated given the fact that teacher learning is 
embodied and complex. Questions that are relevant for such inquiry are: How do teachers situate themselves in schools and their classrooms at the beginning of their careers and over time? How do teachers uniquely choose and organize a subset of teaching phenomena from the totality of possible teaching methods and assemble it in ways consistent with the teacher's prior understanding of the world? (Scheibe, 1995). These are not objective and easy to answer questions because they delve into issues of teacher subjectivities and identities.

Research indicates that a teacher candidate's prior experience linked to teaching and learning impacts the teacher one wishes to become because such experiences are often deeply embedded in the conceptions and attitudes about subject matter, diversity, and students (Olsen, 2011). Additionally, an experience transforms into a learning outcome when it connects to and positively influences future experiences (Alsup, 2006). It is therefore not surprising that Britzman (1991) summarized teacher learning as a struggle for voice and discursive practice amid a cacophony of past and present voices, lived experiences, and available practices. Therefore, teacher preparation programs and hiring school districts cannot afford to ignore the experiential narratives of teachers because they are likely to become internally held narrative scripts that without interrogation or reflection are reproduced materially as pedagogies in classrooms whether they are effective or not (Alsup, 2006).

Teacher identity as a conceptual tool is emerging as a promising way to capture a teacher's situated learning in teaching contexts. Teacher identity also allows an observer to examine how a teacher verifies the self while he plans and enacts teaching (Alsup, 2006; Featherstone, 1992; Mclean, 1999; Olsen, 2011). The main purpose of our study was to explore how teachers constructed professional identities and in particular how they linked their personal subjectivities and beliefs to professional ideologies. We also examined how teachers' identities consequently shaped their conceptions about student demographics and teacher-student interactions. Ultimately, we considered how their identities influenced their interpretations of curricular and school contexts as they constructed what they perceived as effective pedagogies.

Teaching has been compared to learning about oneself (Britzman, 1991; Featherstone, 1992). In Featherstone's study, a participant named Marshall struggled to find a style of teaching that he could manage, so he began to change not only his style but his personality. He worked hard to change what he described as the luxury of a soft, understated personality to that of an actor and a performer. He transformed himself into an extrovert. He also grew a thicker skin and a different kind of detachment and humor. Self as a person and self as a teacher are critical to the process of becoming a teacher because they constitute the personal context within which new information will be interpreted and are the stuff of which a teaching persona is created (Mclean, 1999).

Although learning to teach is individually experienced and hence viewed as individually determined, it is actually socially negotiated. In fact, teachers face dilemmas of carving out their own teaching territory within preordained borders of desiring to be different while negotiating institutional mandates that dictate uniformity (Britzman, 1991). In Britzman's study, Jack planned to conduct an exciting history class similar to his past university's seminars that would create a space for his high school students' critical thinking - he wanted to use a problem-posing instructional pedagogy where he would offer knowledge as a historical product that had to be questioned rather than as wisdom to be accepted. Jack was aware that his students were not used to this form of discourse but did not foresee its implementation as problematic. So in his lesson planning, he decided to give quizzes in the hope that they would keep the students on their toes. Unfortunately, the decision to give quizzes ran counter to the free-flowing critical dialogue Jack had envisioned. Thus, the quizzes complicated the idea of a free-flowing dialogue that would have allowed students to question knowledge as a historical product. These two incidents highlight that teacher learning is a process of negotiation and mediation embedded in multiple sources of knowledge and multiple contexts for practice. Jack and Marshal negotiated both tacit and explicit ways of knowing besides dealing with intuitive and conscious knowledge. Additionally, they had to integrate district and school rules, regulations, policies, group norms and expectations into their pedagogies (Mclean, 1999).

Teacher candidates are more likely to question the discourse that reinforces their beliefs and identity structures if they experience 'cognitive dissonance' in the individual process of learning to teach. Cognitive dissonance translates into transformative learning when a learner is forced to critically reflect and review beliefs and assumptions through the perspective of new and different experiences. Applied to teacher education, transformative learning would enable a professional novice to realize that her source of knowledge is not simply an extant body of facts; rather all learning involves experimental, flexible, creative, compilation of insights, memories, information, associations, articulations, that inform decision-making and action (Jurasaite -Habinson, 2005). At a transformative stage, a teacher comes to know that professional development involves an ability to investigate one's own practices. The teacher becomes an agent of his own learning - a life-long learner or a professional whose readiness to learn depends on individual needs and interests. At the transformational stage 
therefore, a teacher candidate integrates life-long learning as one of his identities. One would argue that teachers who view themselves as life-long learners give teaching multiple visions that extend beyond their own classrooms - even beyond their own teams or departments (Danielson, 2007).

As stated, the main purpose of our study was to explore how professional identities are constructed as teachers linked their personal subjectivities and identities to professional ideologies. In other words, we explored how teachers constructed their identities in the task of teaching. Questions that supported our inquiry were: What narratives are elicited from teacher's perceptions about the following factors: 1. Student demographics, 2. Student-teacher interactions and 3.Curriculum and pedagogical decisions? We, the two researchers, separately interviewed and observed six teachers between 2009 and 2010; three participants of the original six teachers are the subjects of this article. Our three participants are referred in the article using pseudonyms: Teresa, Mickey, and Cathy. These three teachers completed the same teacher education program between 2000 and 2006 and were teaching in the same school district at the time of the study (see Table 1 below). The choice of the three teachers was based on the contrast that they revealed in how they constituted their teacher identities and subjectivities.

Teresa, Mickey, and Cathy had taught for four, five, and eight years respectively. Using teacher identity as a tool for investigation, we negotiated through arrays of their experiences, memories, and resources as they enacted their teaching and talked about their beliefs, perceptions and memories. As we pursued the main purpose of the study, we listened to how the participants made sense of teaching through conversational interviews and through observing several lessons. These methods allowed us to not only hear how our participants viewed themselves as teachers but also saw how they enacted their identities in actual classroom teaching.

\section{Data Collection and Analysis Theoretical Frame}

Kelchtermans \&Vandenberghe (1994) described the way teachers spontaneously think and talk about their practice as a narrative embedded in concrete contexts. Whereas Czarniawska (2004) explained that a narrative requires at least three elements - the original state of affairs, an action or event and consequent state of affairs. It is the perceived coherence of events that determines the plot and the power of the narrative. In our study, interviews and observations mediated the plots and consequences embedded in our participants' narrative. In other words, interviews and classroom observations were not analyzed separately instead they constituted the narratives. Thus, the narratives provided platforms where personal subjectivities and professional ideologies were linked to produce an integrated conception. For example, in the interview Mickey explained how learning stations caused student disruptive behaviors, so she decided to abandon them and chose to use teacher centered methods only. Through observations it was noted Mickey's $5^{\text {th }}$ graders sat passively and listened to her. The teacher's voice pervaded the instructional space; if a student spoke it was when she or he was responding to a teacher's question. The consequence of this teacher centered method was passivity that may have hindered effective learning. The data from the interviews and observations were organized into a plot line that provided the original state of affairs, the actions and the consequence. In our study, narratives facilitated both data collection and analysis. Actions or events in teaching were interpreted using the extant literature; therefore, there are no separate sections for data collection and data analysis. We hope this study fills a gap existing in literature on teacher identity; most of the existing literature focuses on the identity construction of student teachers and beginning teachers. We believe that exploring how practicing teachers construct their identities is an important element in teacher learning both for initial license and continuing professional and personal development. The main purpose of our study was to explore how professional identities emerged as teachers linked their personal subjectivities and beliefs to professional ideologies and practices.

The table below shows the participants as individual cases; it shows when a participant entered and completed the teacher preparation program, the years of experience, and the grade level taught at the time of the study. All three participants attended the same teacher preparation program, were hired in the same school district but were located in different schools. The last column shows the U.S. Federal free and reduced lunch percentages of schools A, B, and C. The Federal free and reduced lunch is a widely used statistic to reflect the socio-economic level of the families served by each school. 
Table 1. Pseudonyms of cases, years of experience, grade level, school and its socio-economic level

\begin{tabular}{llllll}
\hline Name & $\begin{array}{l}* \text { TPP } \\
\text { completion }\end{array}$ & $\begin{array}{l}\text { Years of } \\
\text { teaching }\end{array}$ & $\begin{array}{l}\text { Grade level } \\
\text { taught }\end{array}$ & School & $\begin{array}{l}\text { Free/reduced lunch } \\
\text { Percentages }\end{array}$ \\
\hline$* *$ Teresa & Spring 2006 & 4 & $1^{\text {st }}$ grade & A & $76.8 \%$ \\
**Mickey & Winter 2005 & 5 & $5^{\text {th }}$ grade & B & $82.4 \%$ \\
$* *$ Cathy & Fall 2001 & 8 & $1^{\text {st }}$ grade & C & $26.3 \%$
\end{tabular}

*TPP - Teacher preparation program

$* *$ These are pseudonyms

\section{Narratives and Analyzes}

Each narrative encompassed 3 plot lines organized in interrelated categories namely: student demographics, student -teacher interactions and curriculum and instruction. Consistent with the idea of plots in narratives (Czarniawska, 2004), the description of a teacher's actions and beliefs were closely followed with an analysis and interpretation. For the most part, analysis and interpretation used the extant literature to depict the emerging identity and subjectivities of a study participant.

\subsection{Teresa- School A: Central School District}

\subsubsection{Student Demographics}

At the beginning, Teresa's description of her students sounded clinical: "five students have speech impediment; four students understand but cannot express themselves; a small group live in foster homes, there is also a kid who sounds like she smokes 5 packets of cigarettes daily." However, her diagnosis did not lead to discussion about ameliorating the deficiencies, instead she explained: "I would like my students to love reading - if I can accomplish this objective then I would consider myself successful." Her desire to convince her students that school was a good place was illustrated in what students recited daily: "I love first grade. I am here to learn. I will make good choices. I will have a great day."

Teresa reflected on her experience: "In my first year of teaching, I did not understand all my kids because I had no deep understanding of the different ways that kids learn. I now know my students; I know what a beginning reader looks like. I learn from the student through conversations, observations, and interviews, because there are things that cannot be evaluated through paper/pencil tests." She described beginning readers as students who are "pretty excited, ambitious, and they describe themselves better than they are."

\subsubsection{Student - Teacher Interactions}

The first teacher-student interaction in Teresa's classroom was observed as students arrived in the morning; Teresa was seated at the entrance of her classroom as students arrived. She said hello to them and addressed them using titles such as 'Mr.' 'Ms.' and 'Sir.' She had a small talk with each student. In one conversation, she asked a student: "How is your baby sister?" This question was followed by a conversation about the baby sister's sleeping routine. After the small talks and the homework check, the students were given an information sheet that was expected to go home after school. After this door-way conversation, the student walked into the classroom and began to work on a journal.

Teresa's pedagogy was based on her interactions with her students. In one observation, Teresa was reading a story and the children were sitting at their tables after they had just returned from recess. She interspersed the reading with open-ended questions to predict what her students thought would happen "next" in various crucial events of Charlotte's Web. Charlotte's web connected to the larger theme of a farmer's unit. They began to work on their farmer journals after the teacher's story. As they worked on the journal, Teresa reminded them the song "Farmers Boogaloo" that they had learned earlier. Upon the reminder, students broke into the song "Farmers here, farmers there..." She perceived interactions with students as ways of building bridges of relationships and social skills. Relationships helped her to know her students at a personal level; the personal knowledge enabled her to make curriculum decisions based on the students' interests and experiences. 


\subsubsection{Curriculum and Instruction}

Teresa was aware that school and district policies dictated what and how teachers taught. When the district imposed the use of DRA she referred to that period of implementation as "a year of confusion." She appreciated the tools but questioned the long-term effect of a tool that would not be used in the $6^{\text {th }}$ grade. According to Teresa, the problem with school and district policies is the fact that they "don't talk to us and yet they think they know what we need." It was noted that Teresa was critical of the curriculum and assessment recipes that the school district dictated to teachers. She critiqued and challenged common practices in her school and district. Her narrative showed how a teacher can single-handedly learn from her teaching in order to alter the life chances of her students. She embodied "teacher learning" process effectively.

To Teresa, personal and professional developments were the same thing. After the first year of teaching, she ventured into professional development: "In the middle of the second year of my teaching, I attended a workshop on Daily 5." After that workshop, she decided to toss out stations and basal readers and reconfigured her teaching afresh. According to her, she was among the first people in the district to launch the Daily 5 and used it before it was adopted by the district. She actually helped train her colleagues because she was well ahead of them. The frustration with the basal in the first year of her teaching is the reason she sought a better way: "At the beginning of the basal, one third of the class was ahead and two thirds of the class was behind. At the end of the basal, the reverse took place, two thirds were ahead and one third of the students were behind." This narrative is evidence that Teresa was learning from her teaching.

During the study, Teresa was attending college for her Master's Degree in education. She valued her university experience because "Going to college kept me fresh, I am even worried what I will do when I leave college after graduating." Teresa represented what Halkes and Deijkers (2003) refer to as "cognitive complexity". The argument for cognitive complexity is premised on the view of teaching as intended action in a complex situation. When a teacher has a high level of cognitive awareness, her thoughts and actions are integrated and she displays resourcefulness and high number of constructs. We think Teresa reflected a high level of cognitive complexity because she was engaged in continuous practice-centered and inquiry-oriented professional development (Feiman-Nemser, 2001).

In one of the observed lessons, Teresa gave direct instruction on 'the purpose of reading.' She engaged her students in a conversation based on an open-ended question at the beginning of the lesson: "What are some purposes for reading?" Some students responded that it is important to know words. As her questions became more specific the discussion encompassed students' experiences and interests: she asked "What is the purpose of reading a cook book?" This question encouraged a classroom conversation about the purpose of reading a cook book. She then focused the question on an individual students' interest "What is the purpose of reading about jets, John?" She summarized the lesson on "purpose of reading" saying: You can learn about anything when you read so "to learn about something is the main purpose of reading."

The other big idea was to learn how to check for understanding. She modeled the strategy of "checking for understanding" through role-playing. She asked a student volunteer to play the role of a listener while she read. The volunteer listener was given a book marker as artifact for understanding. After reading for a few minutes the teacher asked the listener: "What animals lived on the farm?" Later there was a role reversal, it was student volunteer turn to read and pose questions to the teacher. Students were asked to pair up to enact the roles of a reader and that of a person who checks for understanding or listener. After a pair of students was formed, they moved to their own space in the classroom where one student was expected to read and ask questions while the listener responded to the questions and demonstrated understanding. The process was complicated for the first graders; they were occasionally confused about the idea of checking for understanding. Cramming big ideas in one lesson may not have been a good plan.

As her lessons unfolded, Teresa demonstrated how she used big ideas in her pedagogy. In the interview she stated: "I teach big ideas that involve asking questions, prediction and engaging characters in a story." The very act of talking about 'big ideas' in a district that mandated standardized teaching and testing was an indication that Teresa's professional identity was informed by other knowledge and values besides the district and school mandates. She was prepared to answer questions pertaining to why her students were studying something, thus engaging the large purpose of education in a democratic society (Kincheloe, 2005). Teresa integrated life-long learning as one of her identities. She viewed teaching from multiple visions that extended beyond her classroom (Jurasaite-Habinson, 2005). 


\subsection{Mickey - School B: Crescent School District}

\subsubsection{Student Demographics}

Mickey taught $5^{\text {th }}$ grade students at the time of the study. She described the community of her students from the perspective of an outsider: "This school is surrounded by a very poor neighborhood. Last year, out of 25 students in $3^{\text {rd }}$ grade only 10 are still here. There is a huge attrition rate. A child is likely to move to 3 or 4 schools in a year." She explained that her students hardly received any support from home and that they were more likely to fend for themselves. She reported that if she sent permission slips home to be signed, she received feedback from the students such as: 'my mom was sleeping when I came to school this morning.' The parents of her students had "temporary, seasonal jobs and worked in the canaries, in agricultural fields, and in hotels as housekeepers." Mickey believed that the students' lived experiences were not useful to her teaching because students spoke Spanish at home that cannot "transfer to school." Asked how she 'saw' poverty in her students' lives she responded: "I see poverty in their scores. I also see it in the double dose or holes in their knowledge because they are missing a lot." It appeared Mickey was unaware that a teacher needs to intimately know the prior knowledge of her students to make learning relevant to them no matter the economic, ethnic or immigration status.

If no worthwhile knowledge emerged from students' experiences, it is no wonder that Mickey assumed her task as a teacher was to be the channel of transmission for knowledge from textbooks to the students. Mickey may not have consciously subverted her students' success, rather her knowledge construction displayed what Brown (2003) described as a low level of cognitive awareness. She was not aware of the meaning and contexts of constructs in teaching such as social constructivism (Au, 1998), culturally responsive teaching (Ladson-Billings, 1992), or funds of knowledge (Moll et al, 1992). Her remarks and attitude appeared to suggest that she rarely interrogated her beliefs and actions to make them at least defendable within the current ways of thinking about learners and especially learners who are from poor and ethnic minority communities. It seemed Mickey's identity maintained a personal ideology about diversity uninfluenced by social-cultural discourses such as multicultural education in college classrooms.

\subsubsection{Student - Teacher Interactions}

In the context of literacy instruction, Mickey mentioned that she had tried to use stations- a literacy work station in an area within the classroom where students work alone or interact with another to explore and expand literacy (Diller, 2008); however she stopped this pedagogical arrangement because "with just me and the behaviors it's kind of difficult to manage behaviors and keep all the materials organized...we had to go back to the whole group instruction." Stations allow students to actively own the learning process; so a teacher using stations cannot have a complete control of the pace, attention, or student interest in a learning context. When Mickey chose to abandon the stations, she inadvertently highlighted her need to have a complete control of the classroom activities to avoid student 'disruptions and misbehaviors.' The intended or unintended consequence of her personal preference was student compliance in place of student divergence and dynamic participation.

The lessons that were observed showed evidence of Mickey's preference; she did not have any student distraction in her 45-minute lesson on volume. Her 22 students were grouped in five rectangular tables arranged in such a way that the students were able to see the reflection of the document camera on a white screen. At the beginning of a 45 -minute lesson she announced to a very quiet class "we're going to learn about volume today." She asked students to imagine a 'packet of milk', a 'balloon' or a 'box of cookies' because volume is the way these different things "take up space." After the brief verbal definition of volume, she asked the students to describe "how one can find the 'area' of the shape up there?" "Up there" was the reflection of an object on document camera that showed cubes around a square object that a student could count to determine the area/volume of the reflected object.

The lesson on volume following the introduction alternated between the teacher's explanation and students' problem solving exercise on worksheets. Students did not speak to one another during the entire lesson despite the fact that they faced each other in the five tables. They were expected to produce individual answers. The only time a student spoke was when a teacher called upon him to answer a question. Five students responded to most questions, so 17 students sat looking either tired or bored. They did not measure anything or touch any objects during the entire lesson on volume. The lesson proceeded from the simple calculations - counting the number of cubes reflected on the object displayed on the screen to more complex problems where students were to determine volume of several boxes: Box A 20x20x20; Box B 15x10x50; Box C 20x15x15. The teacher asked students to "think hard when they failed to produce the correct answers." However hard they thought, they did not get the correct answers to the last three complex problems. The lesson ended abruptly without a recap of what was learned. On a positive note, a lot of material was covered in 45 minutes, however the question on the 
observer's mind was: How much would the students remember at home, or at school about volume when they see a box of cookies or a packet of milk?

Hannaford (1995) remarked that it is unfortunate that in this day and age, activities that permit children to talk through their ideas may be seen by some teachers and administrators as disorderly. From a neurological perspective, pedagogical exercises that require quiet orderly classrooms may actually be inefficient and inappropriate ways of eliciting thinking and understanding. Typical classroom activities that are supposed to promote quiet thinking such as silent reading, filing out worksheets, and drills on lower level skills are often designed more for the purposes of crowd control than education. If Mickey was aware of neurological perspectives on classroom activities, she ignored the advice perhaps in place for an internally held narrative script that advocated for complete control of classroom activities in order to avoid student disruptions and misbehavior. As Brown (2003) argued, the bigger a teacher's resourcefulness or level of cognitive complexity, the higher is her ability to link to what she does and what she knows. One thing was certain about Mickey's view of student learning - 10 year olds can learn through lecture and that an absolutely quiet class without movement or student to student interaction was an effective learning environment. Mickey's desire for complete control of a lesson influenced her choice of the teacher centered instruction methodology. Her desire and choice enacted the teacher identity she had constructed over the years.

\subsubsection{Curriculum and Instruction}

During the interview, Mickey said that math was her favorite subject but she did not enjoy the manipulatives and games in the math textbook because the games and manipulatives hindered students' learning multiplication "fast enough." To help her students learn fast enough she explained: "I use drill to help them; I use charts, cards, and the drill method." Drilling may not be essentially wrong; however, the rationale for drill appeared to be driven by learning speed - an assertion that critics refer to as 'drill and kill.' As one listened to Mickey, it appeared she was not aware of the discourse that a teacher who spends too much time on 'drill and kill' activities may not be getting enough time to develop deeper problem solving and reasoning skills.

The drill aspect of her instructional technique was not limited to math, conversations about language arts showed a similar trend. When asked to describe a student who was struggling in language arts her immediate response was: "one thing that comes to my mind is, in the curriculum they put a lot of emphasis on the "Schwa" sound, which is something I never learned about when I was in school." Her response was not about a struggling student, but about a 'struggling' curriculum. She was more likely to see the content and not the students. Asked to elaborate on the meaning and purpose of the sound "schwa" she responded: "I do not know the purpose of it but students are tested on it." Asked to elucidate how the Schwa sound fit in the big picture of other sounds such as p, $\mathrm{b}, \mathrm{d}$ and so on, Mickey's quick response was: "Oh! I do not teach lower levels. I do not come across the lower level sounds." The focus on a single meaningless sound because it is tested revealed how teaching to the test may make a mockery of learning and teaching. As an interviewer, one wondered how one sound without the context of other sounds was taught. Indeed, as Kincheloe's (2005) asserted "classroom teaching that takes place outside of a rigorous examination of the larger goals of education is always trivialized and degraded (p.2)" At the end of the day, one would argue that Mickey's attention to the Schwa sound trivialized the larger goals of literacy education.

A student teacher who happened to be placed in Mickey's classroom during the study confirmed some of researchers' perceptions. She commented: "The kids get bored with the stories because of the text book format ...it is hard to encourage them." Apparently, Mickey's students followed a static routine based on a basal text complete with the questions. Ironically, the student teacher informed us that she often subverted the static routine handed to her by Mickey and asked pupils more spontaneous and open-ended questions.

It appeared that Mickey saw teaching through the standardized testing and did not pay attention to the student needs for deeper reasoning and critical thinking skills. Her decision to use teacher centered methods of instruction, drill students on narrow aspects of test-driven curriculum may have made her work have certainty and predictability. She also managed to make students completely compliant to the extent that no one would have accused her of failure to control her class. She enacted an identity position that was not bogged in the murky and complex phenomena of student differences. However, literature indicates that those aspects that made Mickey's teaching so predictable and certain deprived her students of meaningful experiences with learning. Indeed as O'Connor (2008) observed, it is the intangible emotional and empathetic qualities that makes a good teacher from students' perspective. Although emotional and empathetic attributes of teaching can't be measured and are likely to be considered worthless, they are the ones that made students feel good about school. Indeed, in 
Mickey's teacher identity we see how the humanist discourse in education has been challenged by the consequences of policies likely to create depersonalized relationships.

\subsection{Cathy-School C: Crescent School District}

\subsubsection{Student Demographics}

Cathy used the income level of the students' homes and their ethnicity to outline characteristics of her students. She reported that most of her first grade students lived within a walking distance to their homes. The average income of their neighborhood was $\$ 112,000$ per household while $90 \%$ of the residents were identified as Caucasians.

Cathy appreciated the collaboration and help that she received from parents of her students. She sent Dolch word books to parents who had struggling students as a resource for homework. She also worked closely with her instructional assistant to help students with the homework and to coach the struggling students. Keeping the reading scores up was no doubt her most important task as a teacher.

\subsubsection{Student -Teacher Interactions}

Cathy mentioned that she used individual conferences to establish relationships with her students. According to her, the philosophy that guided her teaching was to provide structure and organization. In fact, Cathy's classroom was well organized. Books and magazines were placed in transparent plastic containers and piled in very neat, over five feet rows; these rows of books and magazines were also used to subdivide the large classroom area. Every student picked a 12"x 6" plastic container in the morning that had books and other materials from a table placed at the classroom entrance. Students did not check out or touch the numerous books and magazines in their classroom. What were the books and the magazines in the classroom for if students did not use them? It may be when Cathy mentioned that her philosophy was to provide structure and organization that philosophy was encompassed in having a well organized learning space.

Cathy described first grade as hardest of all grades to teach because there was pressure for 'kids to learn to read'. In her narrative, she let her students know that she was there to encourage them and to make their classroom safe Thus, it was her responsibility to "cool their anxiety because some were affected when they realized they could not read as well as their classmates; they became self conscious and made comments such as; 'I cannot read'." She reported that there was a competitive spirit and occasionally students wanted to meet with her to find out if they could move up to the next letter. On hindsight, it appeared Cathy's high expectations may have had unintended consequences including student anxiety. However, in her story, she didn't link students' anxiety to the high expectations.

From the college days, she remembered the Maslow's hierarchy of needs. She reported: "Hierarchy of needs ring true when I have got little 'kiddos' that come to my class and have been to four different schools in the first grade alone. They need to feel safe here." She attributed students' lack of stability or safety solely to reading skills that were "not up to par." Cathy met the safety needs by diagnosing reading skills that were "not up to par" and worked to overcome the deficiencies. It was rather disconcerting when Cathy interpreted "being at par on reading skills" as a safety need. Did the idea that a child could not read as well as her classmates' amount to lack of a basic need as per Maslow Hierarchy? What led to Cathy's unique interpretation of this theory?

Cathy diagnosed reading deficits through measuring tools such as Diagnostic Reading Assessment (DRA) and was able to determine the students who needed coaching. Each student's reading score was the single-most important factor in Cathy's class. She did not narrate how she used multiple data from interviews and observations to really understand the "kiddos who have been to four different schools." It appeared the market driven high stakes testing had contributed to Cathy's desire to explain students' needs through the tangible reading score and not the intangible and difficult to measure empathetic qualities (O'Connor, 2008)..

She described her personality as "touchy feely" and therefore creating a warm environment for her students "came naturally". She therefore stayed away from the gimmicks that other teachers used such as points and cards. As observers of Cathy's teaching, we did not observe any 'touchy feely' moments if that means encounters with a teacher who was inviting, and who engaged students in free flowing dialogues that allowed self-expressions. Instead, our observation was an image of a business-like teacher who moved rapidly through lessons and who did not use open-ended strategies even when discussing stories. Story discussions had the atmosphere of a test; there was a correct and incorrect answer for every question. It is doubtful that Cathy engaged a critical inquiry that 'penetrated' the tacit reality that she constructed in her classroom. The statement that creating a warm environment for students came naturally to her reveals the problematic nature of learning to teach in isolation. If 
reflective practice prevailed in Cathy's school, she would have known that she was not a 'touchy feely' person from others' perspective.

\subsubsection{Curriculum and Instruction}

Cathy explained that her school's Annual Yearly Report was graded as 'outstanding' so there was a lot of pressure on teachers to keep the school on the outstanding status. To maintain this category, the school had what Cathy described as "non-negotiable practices." Non-negotiable meant that teachers had to distribute instruction time uniformly - 90 minutes for literacy, 60 minutes for writing, and 60 minutes for math. There was no time allocated for art, history, health, science, social studies and so forth. She viewed the idea of 'non negotiable' as no fun but was resigned to it because according to her the district administrators gave the mandate to the principal of a school, and then the principal passed it down to the teachers. The mandates, one would argue, had a great influence in Cathy's teacher identity. She felt she had little choice but meet the demands. We did not sense any dissatisfaction with high stakes testing on her part. Unlike the teachers depicted in MacLure's (1993) study who reported a deep sense of alienation from the values and practices of their institution or central government, Cathy did not criticize her district policies.

Cathy took her teacher role as a diagnostician seriously. On assessment she stated: "we do have this formal assessment PLA which I heard is going away, they are now bringing in something new next year called DRA." According to Cathy, the DRA or Diagnostic Reading Assessment was an added task because she took approximately 45 minutes to "sink data into the assessment tool for one student at a time." She hoped they (the district and school supervisors) did not withdraw DRA as they had withdrawn the Dibels diagnostic tool which she liked. Our conclusion about Cathy is that when a teacher has not built a strong identity based on her beliefs and knowledge about learning and teaching, official mandates appear to be the blue-print of a teaching task. Lack of a firm belief about learning grounded in literature and experience marked Cathy's teacher identity.

It was sometimes difficult to separate Cathy's authentic thinking and her views on the school mandates. As a diagnostician, she collected information from the measurement tools and organized ways of ameliorating student deficiencies. It was likely Cathy did not question the meaning her students derived from curriculum because her attention was focused on one aspect of the school structure - the high stakes test score.

We observed reading and math lessons in Cathy's classroom. The reading lesson took well over 80 minutes and it was subdivided into 4 mini-lessons. The first 20 -minute reading lesson, Cathy invited students to sit in a semi-circle on the carpet in front of her rocking chair. To introduce the theme of the lesson she asked: "how does looking at a picture on a cover of a story book help you? What do you see on the cover? She held the big book high for students to see the cover. Students offered diverse responses of what they saw - some identified frogs, others goats, others cows and so on. She did not use the "wrong" responses in a classroom conversation because she was looking for a 'correct' answer.

The second 20 minute lesson was introduced with the questions: What is the initial sound in a word? Is it at the beginning or in the middle of a word? The term 'initial' confounded the first-graders so the teacher was forced to explain the meaning of the term initial, however her explanation was even more confusing because she gave an example of a person's name and its "initials". She corrected her earlier interpretation of 'initial' letters and so students effectively identified the initial sounds of several words including 'da' for 'dog'. After the lesson the students took a break, and they went to their nooks for individual reading.

The third lesson had a different theme and students were expected to listen to the story and fill blanks in a sentence. For example 'its (tadpole) tail got_ and _ . The fourth lesson was somehow similar to the $3^{\text {rd }}$ lesson. Students were required to listen to the story, and understand 4 words in their contexts. The words were 'assortment', 'civilized', 'contributed' and 'inappropriate.' The reading of the story was so rapid that the observer did not hear the words in their context. Although the definitions of the words were later given, for the most part, students did not connect the meanings with the context.

All four mini- lessons demanded exacting listening skills. Nothing was written on an overhead or on a board to help the visual and tactile learners. Furthermore, even for those who learn best through listening it could have been immensely helpful if the teacher slowed, paused, and deliberately repeated words and phrases that were poignant to the flow of the stories and the questions. Additionally the stories would have connected with students if the teacher viewed their contents through her students' lenses by discussing the students' responses. This emphasizes the need to view teaching from a professional learning communities' (PLC) perspective where other teachers would give honest comments and reviews to a colleague. 
One of the decisions that the teacher made for the 80-minute reading lesson is to cover a lot of material. The students could have been given more time to construct their own knowledge or learn from their 'mistakes.' If the goal of 80-minute reading lesson was to help students grow into inquiring and resourceful individuals, the goal was not achieved. If the goal was for the teacher to read several stories to the students followed by a few questions, the objective was accomplished.

In a math lesson observed later, Cathy gave the students five steps: "read, draw a picture, solve the problem, and then label." The students were told to follow the steps individually in their "offices." The office was a manila paper folded around a student's desk to block other students from view. The observer noted that the students were trying, as hard as they could, to see each other's work. It was obvious to the students that the decision to have them work in their offices was to curb cheating. From the observer's vantage point, the surveillance created tension and some sort of fear in the room. To disperse the fear, the teacher explained that if a student missed a step she or he would "not be in trouble." The observer concluded that the fear emerged from the test-like environment. Cathy's instrumental method of instruction in both reading and math resonated with students' compliance and mastery of skills. However, as Hannaford (1995) indicates, pedagogical exercises that require quiet orderly classrooms may actually be inefficient and inappropriate ways of eliciting thinking and understanding.

How Cathy understood the self in the context of her classroom practice was contra to how we, the observers experienced her interaction with students. After eight years of teaching, she had developed strong beliefs about teaching. However, she did not critically engage some of her beliefs or practices to experiment diverse methods in her pedagogy. She constructed a teacher identity that was fully satisfied with teaching to the test to raise the reading scores not so much to help students learn, but rather to maintain the acclaimed school status.

\section{Conclusions}

Teacher identity is the outcome of the interaction between personal experiences of teachers and the social, cultural, and institutional contexts in which they perform their task of teaching on daily basis (Jurasaite-Harbison, 2005). Through each teacher's narrative constructed from in-depth interviews and observations, we were able to examine how a teacher's beliefs and enactment of teaching and other school experiences connected to shape a distinct teacher identity. As Alsup (2006) states, experiential narratives are influential in the development of teacher identity, Cathy, Mickey and Teresa had very different teacher identities despite the fact that they attended the same teacher education program and taught in the same school district.

For Cathy, school district mandates pressured her to perform. She knew as long as she kept those scores up, there would be no reckoning from her superiors. She interpreted this to mean the process of teaching and learning was less important than the product signified by the standardized score. She saw the students through the lenses of whether they were at par or not. The students' middle class status assisted her to achieve this goal - parents reinforced reading at home, students were coached by the class aide and so the first graders in Cathy's class read at and above grade. The Annual Yearly Report of the school remained at "outstanding."

It is not difficult to connect the high stakes context of teaching with the decisions that Cathy was making in her curriculum and pedagogy. Both the math and reading lessons observed in different days by two different observers depicted a teacher who was extremely fast-paced and who demanded from her students nothing but correct responses or answers. It may be true to argue that she had not developed skills for negotiating and mediating knowledge embedded in multiple sources and multiple contexts (Britzman, 1991). Had she been able to negotiate different contexts and sources of knowledge perhaps she would have created a relaxed learning environment during instruction, but demanded individual work when giving a test. Perhaps she would also have listened to the stories of the "kiddos" who had been to four different schools to inform her pedagogy instead of interpreting their mobility as a deficiency.

We were not sure if Mickey's disposition of detachment with her students' community was a result of a personal ideology or it was an aspect of ignorance. Mickey saw void and barriers in her students' current and prior experiences. Her students' parents were poor and spoke Spanish so their situations in life would not offer anything to school curriculum and pedagogy. Mickey implemented complete control of her classroom as her students sat motionless. We think Mickey's school context did not tolerate what she described "difficult to manage behaviors" so she passionately wanted to have complete control of the classroom processes. Unless she gets a supervisor or trusted colleague who may encourage her to be reflective on all aspects of learning and teaching, Mickey is likely to continue with her mistaken belief that children learn best when they passively listen to a teacher transmitting knowledge to them. The complete control came with teaching to the test even when the test demanded meaningless sounds and contents. 
Finally, it was in Teresa's classroom we ascertained that what teachers do, believe, and value can be manifested in the artifacts of their classroom. Teresa celebrated her students' self-expression and their discovery in learning and personal growth. The process of learning was truly more meaningful to her, than the standardized scores. She may have learned to negotiate and mediate multiple sources and multi-contexts by seeking knowledge through personal reading and college courses. Teresa decided to see possibility in her students and was determined to help all her students find meaning and value in their learning to read. Thus she constituted an identity of a life-long learner. A learner saw teaching and learning process as experimental, flexible, and creative where the thinking, feeling, perceiving and behaving were allowed in the learning process.

Mickey, Cathy and Teresa identities shaped their views about students, of themselves as teachers, and finally their identities informed curriculum and pedagogy choices. Professional identity yields a rich understanding of the relationship between self and the context of teaching practice (Jurasaite-Harbison, 2005). Finally we observe, schools will be transformed when teachers will see themselves as life-long learners and view teaching from multiple visions that extend beyond their classroom walls (Danielson, 2007).

\section{References}

$\mathrm{Au}, \mathrm{K}$. H. (1998). Social constructivism and the school literacy: Learning of students of diverse backgrounds. Journal of Literacy Research, 30(2), 297-319. http://dx.doi.org/10.1080/10862969809548000

Alsup. (2006). Teacher identity discourses: Negotiating personal and professional spaces. Mahwah, New Jersey: Lawrence Erlbaum Associates.

Britzman. (1991). Practice makes practice: A critical study of learning to teach. New York, NY: State University of New York Press.

Brown, A. F. ( 2003). Professional literacy, resourcefulness, and what makes teaching interesting. In M. Kompf, \& P. M Denicolo (Eds.), Teacher thinking twenty years on: Re-visiting persisting problems and advances in education. Exton, PA: Swets \& Zeitlinger.

Czarniawaska-Joerges, B. (2004). Narratives in social science research. Thousand Oaks, CA: Sage Pub.

Danielson, C. (2007). The many faces of leadership. Educational Leadership, 65(1), 14-19.

Darling-Hammond, L., Bradford J., Derry, S., Berliner, D, Hammerness, K., \& Beckett, K. L. (2005). Preparing teachers for a changing world: What teachers should learn and be able to do. San Francisco, CA: John Willey \& Sons.

Diller, D. (2008). Making literacy stations work for K-to 2 teachers. CREC Institute of teaching and learning. Hartford: CT.

Featherstone, H. (1992, July). Learning from the first years of classroom teaching: The journey in, the journey out. Michigan State University: National Center for Research on Teacher Learning.

Feiman-Nemser, S. (2001). From Preparation to Practice: Designing a Continuum to Strengthen and Sustain Teaching. Teachers College Record, 103(6), 1013-1055. http://dx.doi.org/10.1111/0161-4681.00141

Halkes, R., \& Deijkers, R. (2003). Teaching' teaching criteria. In M. Kompf, \& P. M Denicolo (Eds), Teacher thinking twenty years on: Re-visiting persisting problems and advances in education. Exton, PA: Swets \& Zeitlinger.

Hannaford, C. (1995). Smart moves: Why learning is not all in your head. Arlington, Va.: Great Ocean Publishers.

Jurasaite-Harbison, E. (Unknown). Reconstructing teacher's professional identity in a research discourse a professional development opportunity in an informal setting. TRAMES Journal of the Humanities and Social Sciences, 9(2), 159-176.

Kelchterman, G., \& Vandenberghe, R. (1994). Teacher's professional development: A biographical perspective. Journal of Curriculum Studies, 26, 45-62. http://dx.doi.org/10.1080/0022027940260103

Kincheloe, J. L. (2005). What are we doing here? Building a framework for teaching. In J. Kincheloe (Ed.), Classroom teaching: Introduction (pp. 1-24). New York: Peter Lang Publishing

Ladson-Billings, G. (1992). Reading between the lines and beyond the pages. A Culturally Relevant approach to literacy teaching. Theory into practice, 31(4), 312-320. http://dx.doi.org/10.1080/00405849209543558

Mclean, S. V. (1999). Becoming a teacher: The person in the process. In R. P. Lipka, \& T. M. Brinthaupt (Eds.), The Role of Self in Teacher Development (pp. 55-91). New York Press SUNY. 
MacLure, M. (1993). Arguing for your self: Identity as an organizing principle in teachers' jobs and lives. British Educational Research Journal, 19(4), 311-322. http://dx.doi.org/10.1080/0141192930190401

Marzano, R. (2003). Classroom management that works: Research based strategies for every teacher. Alexandria, VA: Association for Supervision and Curriculum Development.

Moll, L. C., Amanti, C., Neff, D., \& Gonzalez, N. (1992). Theory into Practice, 31(2), 132-141. http://dx.doi.org/10.1080/00405849209543534

National Council for Accreditation of Teacher Education (NCATE). (November, 2010). Report of the Blue Ribbon Panel on Clinical Preparation and Partnerships for Impoved student learning.

O'Connor, K. E. (2008). "You choose to care": Teachers, emotions, and professional identity. Teaching and teacher education, 24, 117-126. http://dx.doi.org/10.1016/j.tate.2006.11.008

Olsen, B. (2011). I am large, I contain multitudes'. Teacher identity as a useful frame for research. Practice and diversity in teacher education. In A. F. Ball, \& C. Tyson (Eds.), Studying Diversity in Teacher Education. New York: Rowman and Lttlefield publishers.

Scheibe, K. E (1995). Self Studies: The Psychology of Self and Identity. Westport, CT: Praeger.

Tickle, L. (1999). Teacher self appraisal and appraisal of self. In R. P. Lipka, \& T. M. Brinthaupt (Eds.), The Role of Self in Teacher Development (pp. 121-141). New York Press SUNY.

\section{Copyrights}

Copyright for this article is retained by the author(s), with first publication rights granted to the journal.

This is an open-access article distributed under the terms and conditions of the Creative Commons Attribution license (http://creativecommons.org/licenses/by/3.0/). 